\title{
A LEX MERCATORIA ENQUANTO DIREITO: UMA ANÁLISE DA NATUREZA DAS NORMAS QUE REGEM O COMÉRCIO INTERNACIONAL À LUZ DA TEORIA DO ORDENAMENTO JURÍDICO DE NORBERTO BOBBIO
}

\author{
THE LEX MERCATORIA WHILE LAW: AN ANALYSIS OF THE NATURE RULES \\ THAT CONDUCT THE COMMERCE IN THE LIGHT OF THE NOBERTO BOBBIO'S \\ LEGAL ORDER THEORY
}

\begin{abstract}
Madson Douglas Xavier da Silva Aurélio Agostinho da Bôaviagem²
\end{abstract}

\section{RESUMO}

No âmbito do Direito Internacional Privado, a Lex Mercatoria, teorizada como um conjuntos de normas criadas e utilizadas pelo comércio internacional, é um tema profundamente debatido, especialmente nas últimas décadas. A discussão acadêmica abordou desde a existência ou não deste conjunto de normas costumeiras desde tempos remotos e seu conceito, até a análise mais contemporânea quanto à natureza da Lex Mercatoria, se esta forma um sistema jurídico, se pode haver um Direito sem o Estado ou além deste. Com efeito, o presente trabalho pretende analisar a Lex Mercatoria enquanto Direito, à luz da Teoria do Ordenamento Jurídico de Norberto Bobbio, investigando se as normas consuetudinárias do comércio internacional possuem os elementos típicos à constituição de um ordenamento jurídico apontados pelo jurista italiano. Como parâmetro necessário, este artigo analisará se as normas da Lex Mercatoria constituem uma unidade, se demonstram coerência e completude, e se são aptas a estabelecerem relações com outros ordenamentos jurídicos, uma vez que estes quatro critérios são apontados pela Teoria do Ordenamento Jurídico como constitutivos de um ordenamento jurídico, ao passo que o autor entende que uma definição satisfatória do Direito só é possível sob a ótica do ordenamento jurídico.

Palavras-chave: Teoria do Direito; Teoria do Ordenamento Jurídico; Lex Mercatoria; Direito Internacional Privado; Comércio Internacional.

\section{ABSTRACT}

At the scope of Private International Law, the Lex Mercatoria, theorized as a set of standards created and used by the international commerce. It is a topic that has been deeply discussed, especially, in the last decades. Since the existence or not, the academic's discussion approached this set of usual standards syne the remote time and its concept, even the most contemporary analysis as many as the Lex Mercatoria's nature. If it can make a law system, if it can have a law without state or beyond that. With effect, the actual work pretends to analyze the Lex Mercatoria as Law in the light of the Noberto Bobbio's legal order, investigating if the international consuetudinary's commerce rules have the typical elements to the constitution of legal order indicated by the Italian lawyer. With the necessary parameters, this article will analyze

\footnotetext{
${ }^{1}$ Mestrando em Direito pelo Programa de Pós-Graduação em Direito da Universidade Federal de Pernambuco. Advogado. E-mail: madsonxavier@hotmail.com

${ }^{2}$ Professor Emérito da Universidade Federal de Pernambuco. Professor Permanente do Programa de Pós-Graduação da Faculdade de Direito do Recife, da Universidade Federal de Pernambuco. Mestre e Doutor em Direito pela mesma instituição. Advogado. E-mail: aurelioboaviagem@gmail.com
} 


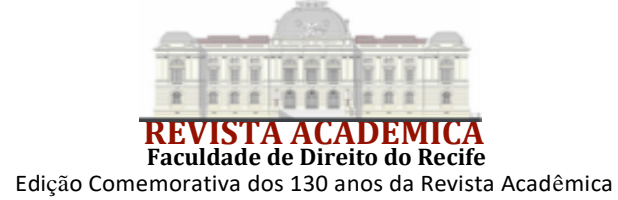

if the Lex Mercatoria rules compose a unity, if demonstrate coherence and completeness and if it is able to establish relationship with others legal orders, once this for criteria are pointed by the Legal Order Theory as constitutive as a legal order while the author understands that a satisfactory definition of law is just possible under sight of the legal order.

Keywords: Theory of Law; Legal Order Theory; Lex Mercatoria; Private Internacional Law; Internacional Commerce.

\section{INTRODUÇÃO}

Especialmente a partir da segunda metade do século XX, o comércio internacional alcançou um grau de relevância e ramificação ao redor do globo em proporções nunca antes atingidas. Tal cenário, em parte derivado da crescente aprimoração dos meios tecnológicos no pós II Guerra Mundial, deu origem ao conceito de "aldeia global" desenvolvido por Marshall Mc Luhan, em 1964, que defendia que uma nova realidade estava sendo moldada através da aproximação dos povos pela tecnologia, e que o mundo estaria se tornando cada vez menor, ante a facilitação das trocas de informações e mercadorias entre fronteiras.

Contudo, o comércio entre fronteiras, hoje tido por "internacional", não é um fenômeno novo na humanidade, havendo fartas evidências de que desde a Antiguidade a prática do comércio entre diferentes povos já era comum. Aos antigos fenícios, por exemplo, é atribuída a característica de terem sido os melhores comerciantes de seu tempo, exercendo comércio em todo o Mediterrâneo, desde a região do Levante até onde hoje se situam o sul de Portugal e o norte do Marrocos, e desenvolvendo um dos primeiros modelos de "economia mundial". No mesmo esteio, as origens da civilização grega estão calcadas no comércio marítimo entre as cidades por meio do Mar Egeu e Mediterrâneo.

Desde a Antiguidade, as relações de comércio, como qualquer outra relação humana, são pautadas por normas que regulamentam as trocas entre pessoas, muitas vezes de diferentes povos, que determinam o comportamento a ser observado entre os negociantes.

Nesse contexto, parcela dos doutrinadores do Direito Internacional Privado passou a defender a existência desde a Antiguidade e a Idade Média de um conjunto de normas reguladoras do "comércio internacional",, denominada de Lex Mercatoria, que seria aplicado pelos comerciantes em maior ou menor grau de homogeneidade no mundo conhecido até então.

Grandes debates já foram feitos questionando a existência da Lex Mercatoria, se os antigos costumes de comércio entre os povos formavam ou não um conjunto normativo coeso e amplamente aceito, sua eventual natureza jurídica e abrangência. Outros debates mais recentes, que ultrapassaram a antiga discussão quanto à existência da Lex Mercatoria, cuidaram de analisar se a "nova" Lex Mercatoria, derivada das relações de comércio internacional desde a Idade Moderna até a contemporaneidade, poderia ser considerada uma continuação da "antiga" Lex Mercatoria, debate este temperado pela indagação sobre ser possível ou não a existência de lei sem o Estado ou além deste.

Com base nesse prelúdio, o presente artigo se destina a investigar especificamente se a Lex Mercatoria pode ou não ser considerada Direito e se este conjunto de normas costumeiras do comércio internacional pode ser classificado como um ordenamento jurídico.

Como recorte metodológico necessário à abordagem do objeto, o estudo utilizará a Teoria do Ordenamento Jurídico de Norberto Bobbio como referencial que estabelece as premissas e fundamentos de um ordenamento jurídico. Este parâmetro servirá para testar a hipótese de que a

3 O termo "internacional" é utilizado aqui com a devida licença, haja vista que no contexto em debate não existia sequer a ideia de Estado-nação ou de fronteiras nacionais, sendo certo que a existência do "internacional" presume antes a existência do "nacional".

SILVA, Madson Douglas Xavier da; BÔAVIAGEM, Aurélio Agostinho da. A LEX MERCATORIA ENQUANTO DIREITO: 


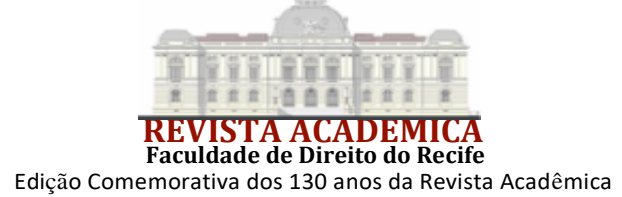

Lex Mercatoria careceria de elementos caracterizadores da juridicidade de um sistema normativo, de modo que esta não possuiria status de Direito. Em suma, o cerne está centrado no questionamento de como Norberto Bobbio veria a Lex Mercatoria.

De modo a tornar didático o presente estudo, a primeira parte deste trabalho irá se debruçar sobre a Teoria do Ordenamento Jurídico, e fazer uma análise sobre os quatro elementos apontados por Norberto Bobbio como comuns e caracterizadores dos ordenamentos jurídicos - unidade, coerência, completude e as relações com os demais ordenamentos jurídicos.

A segunda parte deste estudo irá abordar os aspectos pertinentes à Lex Mercatoria, sua difícil conceituação pela doutrina, os costumes do comércio internacional, bem como retratará o recorrente debate se esta é um Direito sem o Estado ou além deste.

Por fim, o terceiro capítulo deste artigo irá, com base nas premissas anteriormente estabelecidas, propriamente analisar se a Lex Mercatoria possui os elementos apontados pela teoria de Bobbio que a possam caracterizá-la como um ordenamento jurídico e se efetivamente este conjunto de normas costumeiras pode ser considerado Direito.

\section{BREVES APONTAMENTOS SOBRE A TEORIA DO ORDENAMENTO JURÍDICO DE NORBERTO BOBBIO}

O que diferencia o Direito das demais regras de conduta? O que torna uma norma dotada de caráter jurídico? O que caracteriza algo como Direito? Não raro essas perguntas foram e ainda são objeto de estudo pelos teóricos do Direito.

Um dos estudiosos do tema foi o jurista italiano Norberto Bobbio (1909-2004), que na busca pela compreensão do que é o Direito formulou a sua Teoria Geral do Direito, constituída por dois volumes: a Teoria da Norma Jurídica e Teoria do Ordenamento Jurídico. Este último se constitui o referencial teórico pelo presente trabalho.

No primeiro volume, Bobbio estudou a norma jurídica isoladamente, enquanto argumentava que "os problemas gerais do direito foram tradicionalmente mais estudados do ponto de vista da norma jurídica, considerada como um todo que se basta a si mesmo, que do ponto de vista da norma considerada como parte de um todo mais vasto que a compreende ${ }^{4 \%}$.

Nesse sentido, o próprio autor admite que a sua análise anterior do Direito sob a ótica da norma jurídica trouxe alguns problemas ${ }^{5}$ que não puderam ser resolvidos pela Teoria da Norma Jurídica, e que somente poderiam ser solucionados através da análise do Direito enquanto ordenamento. Um dos problemas insolúveis apontados pelo jurista foi a constatação de que não é possível se chegar a uma definição do Direito do ponto de vista da norma jurídica, considerada isoladamente. A partir de então, Bobbio elaborou a sua Teoria do Ordenamento Jurídico, motivado pelo "fato de que, na realidade, as normas jurídicas nunca existem isoladamente, mas sempre em um contexto de normas com relações particulares entre si ${ }^{6 "}$.

Mais adiante, Bobbio aponta que os pioneiros no debate sobre a realidade do ordenamento jurídico foram os teóricos da instituição ${ }^{7}$, mencionando como o grande expoente dessa linha o

4 BOBBIO, Norberto. Teoria do Ordenamento Jurídico. Trad. Ari Marcelo Solon. 2. ed. São Paulo: Edipro, 2020. p. 36.

5 Dentre os problemas apontados está o debate quanto à existência de normas jurídicas desprovidas de sanção, e se este elemento seria indispensável à conceituação de norma jurídica. Este ponto será melhor debatido adiante neste trabalho.

6 Idem, p. 35.

7 Bobbio trata da teoria do Direito como instituição no primeiro livro (Teoria da Norma Jurídica), que defende que o conceito de Direito necessita de três elementos essenciais: 1) "não há sociedade, no sentido correto da palavra, sem que nela se manifeste o fenômeno jurídico (ubi societas ibi ius)"; 2) "O conceito de direito deve, em segundo lugar, conter a ideia de ordem social: o que serve para excluir cada elemento que conduza ao arbítrio puro ou à força 


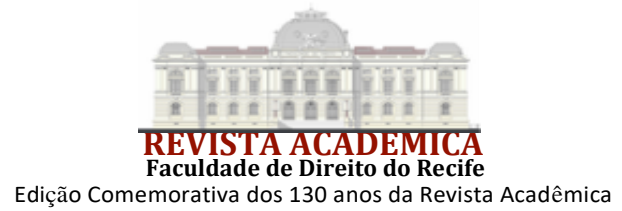

jurista Santi Romano. Ao largo de alguns problemas da teoria da instituição criticados por Bobbio e irrelevantes para a finalidade do presente estudo, esta teoria prestou uma grande contribuição ao "pôr em relevo o fato de que só se pode falar em Direito onde haja um complexo de normas formando um ordenamento 8 ".

Com base nessa inovação estabelecida inicialmente pelos institucionalistas, o Bobbio coloca as linhas mestras da sua Teoria do Ordenamento Jurídico ao delimitar que Direito não é norma, mas um conjunto coordenado de normas. Assim, entende ser impossível a existência de uma norma sozinha, e que o comando normativo sempre estará ligado a outras normas, que em conjunto formam um sistema. Em outras palavras, "uma definição satisfatória do Direito só é possível se nos colocarmos do ponto de vista do ordenamento jurídico"”.

Prossegue o autor ensinando que na tentativa de caracterizar o Direito com base em algum elemento da norma jurídica, teria que se considerar pelo menos quatro critérios suscintamente aqui apresentados: 1) critério formal - Direito é aquilo que observa qualquer elemento estrutural das normas que se convencionou chamar de jurídicas; 2) critério material - Direito enquanto a extração do conteúdo das normas jurídicas, ou seja, das ações reguladas; 3) critério do sujeito que impõe a norma - jurídicas são as normas emanadas pelo poder soberano (teoria da soberania), compreendido como aquele que possui o monopólio da força; e 4) critério do sujeito ao qual a norma é destinada - numa primeira perspectiva, a norma jurídica é aquela cujo destinatário tem convicção de sua obrigatoriedade, e numa segunda perspectiva, são aquelas normas destinadas ao juiz, aplicador da norma ${ }^{10}$.

Dentro deste último aspecto da norma jurídica é que se insere a interpretação, tanto pelo magistrado quanto pelo destinatário do mandamento, na medida em que a aceitação e a eficácia de determinada norma enseja a capacidade do intérprete de absorver e transmitir uma prescrição compatível das ideias do ordenamento ${ }^{11}$. Assim, o quarto critério da norma jurídica apresentado pelo jurista italiano se aproxima da necessária interpretação desta, na medida em que não há norma jurídica que dispense interpretação ${ }^{12}$, e se aproxima do método concretista de interpretação tratado por Paulo Bonavides, que gravita ao redor de três elementos básicos: a norma que vai se concretizar; a compreensão prévia do intérprete (realismo) ${ }^{13}$ e o problema concreto a resolver ${ }^{14}$.

Contudo, Bobbio aponta que os quatro critérios apresentados não são suficientes para uma definição satisfatória do Direito, tanto é que, com base na Teoria da Norma Jurídica, o autor apenas conseguiu limitar uma definição particular da norma jurídica, que se dá "através da sanção, e a sanção jurídica através dos aspectos de exterioridade e institucionalização, donde a definição de norma jurídica como aquela norma cuja execução é garantida por uma sanção externa e

material"; e 3) a ordem social, "antes de ser norma, antes de concernir a uma simples relação ou a uma série de relações sociais, é organização, estrutura, situação da mesma sociedade em que se desenvolve, e a qual constitui como unidade, como ente por si só". In: BOBBIO, Norberto. Teoria da Norma jurídica. Trad. Fernando Pavan Baptista e Ariani Bueno Sudatti. 6. ed. Bauru: Edipro, 2019. p. 30.

8 BOBBIO, Norberto. Teoria do Ordenamento Jurídico. Trad. Ari Marcelo Solon. 2. ed. São Paulo: Edipro, 2020. p. 37.

$9 \quad$ Idem, p. 38.

$10 \quad$ Idem, p. 38-41.

11 KRELL, Andreas. Entre desdém teórico e aprovação na prática: os métodos clássicos de interpretação jurídica. Revista Direito GV, São Paulo, v. 10, n. 1, p. 295-320, jan./jun. 2014.

12 BONAVIDES, Paulo. Curso de Direito Constitucional. 15. ed. São Paulo: Malheiros, 2004. p. 437.

${ }^{13}$ Quanto à diversidades de interpretação da norma, Hans Kelsen contribui com o tema ao afirmar que os indivíduos "precisam compreender e, portanto, determinar o sentido das normas jurídicas que por eles hão de ser observadas. (...) Dessa forma, existem duas espécies de interpretação que devem ser distinguidas claramente uma da outra: a interpretação do Direito pelo órgão que a aplica e a interpretação do Direito que não é realizada por um órgão jurídico mas por uma pessoa privada”. In: Teoria Pura do Direito. Trad. João Baptista Machado. 8. ed. São Paulo: WMF Martins Fontes, 2009. p. 387-388.

14 Idem, p. 481-482.

SILVA, Madson Douglas Xavier da; BÔAVIAGEM, Aurélio Agostinho da. A LEX MERCATORIA ENQUANTO DIREITO: UMA ANÁLISE DA NATUREZA DAS NORMAS QUE REGEM O COMÉRCIO INTERNACIONAL À LUZ DA TEORIA DO ORDENAMENTO JURÍDICO DE NORBERTO BOBBIO. Revista Acadêmica da Faculdade de Direito do Recife - ISSN: 24482307, Edição Comemorativa dos 130 anos da Revista Acadêmica, p. 178-198. Nov. 2021. ISSN 2448-2307. <Disponível em: https://periodicos.ufpe.br/revistas/ACADEMICA/article/view/252575> 


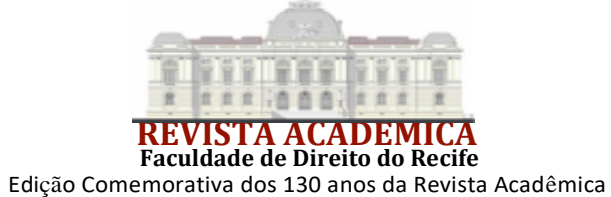

institucionalizada ${ }^{15}$ ". Nesse esteio, do ponto de vista da norma só é possível extrair uma definição da própria norma, mas não uma definição de Direito.

Para os fins presentes, essa conceituação suscinta e precisa de Bobbio a respeito da norma jurídica contribuirá com a terceira parte deste artigo, que fará uma análise se a Lex Mercatoria possui elementos suficientes para ser considerada Direito.

Neste contexto, Bobbio defende que para que haja Direito, é necessário haver, ainda que de modo diminuto, uma organização, um completo sistema normativo, que além da previsão da conduta e de sua consequência, permita e viabilize imperativamente o seu cumprimento. Essa é a noção de sanção organizada, que, segundo o autor, leva necessariamente à procura do "caráter distintivo do Direito não em um elemento da norma, mas em um complexo orgânico de normas", em suma, ao ordenamento jurídico. Quanto a este ponto, Bobbio arremata seu pensamento ao defender que somente no âmbito de uma teoria do ordenamento é que o fenômeno jurídico encontra sua adequada explicação.

Ainda dentro do debate quanto à sanção jurídica, Bobbio apresenta uma solução para um "problema mal resolvido" derivado de sua análise do Direito pela ótica da norma jurídica no seu livro predecessor. Na Teoria da Norma Jurídica, o jurista italiano se deparou com a existência de normas jurídicas desprovidas de sanção. Assim, o autor teve que responder se a sanção faz parte do caráter essencial das normas jurídicas, e se as normas desprovidas de sanção seriam ou não jurídicas. Ao confrontar o problema pela perspectiva do ordenamento jurídico, Bobbio chegou à compreensão de que é possível a existência de norma jurídica sem sanção, uma vez que o ordenamento jurídico não pressupõe que todas suas normas sejam sancionadoras, mas que apenas a maioria das normas do sistema sejam dotadas de sanção ${ }^{16}$.

Uma discussão interessante trazida pelo autor diz respeito à pluralidade de normas e a possibilidade de haver, no plano da existência, um ordenamento jurídico formado por uma norma única. Quanto a este ponto, Bobbio é enfático ao rechaçar tal configuração de ordenamento, isso porque compreende que a própria definição de ordenamento jurídico está conscrita a um conjunto de normas e esta é a única condição exigível. Assim, para a constituição de um ordenamento, é necessário que concorram pelo menos duas normas.

Este posicionamento veemente de Bobbio se deve à sua concepção de que a regulamentação trazida por uma regra de conduta "consiste em qualificar uma ação através de uma das três modalidades normativas (ou deônticas): do obrigatório, do proibido e do permitido". De outra banda, o referido autor considera inconcebível a existência de "um ordenamento que regule todas as ações possíveis com uma única modalidade normativa ${ }^{17}$ ".

Dentro desta perspectiva, Bobbio formula um interessante raciocínio ao entender que as normas sempre se desdobram em pelo menos duas: a geral e a particular exclusiva, "ainda que quando formulada em uma só". Assim, uma norma proibitiva que vede determinado comportamento traz atrelada a si um outra norma (excludente) que permite todas as demais condutas não contrárias à vedação. Com isso, ainda que se esteja diante de um ordenamento embasado em uma única prescrição, na realidade se está diante de um conjunto formado por ao menos de duas normas. Cada norma traz sua razão e a permissão daquilo que a não contrarie.

Outro ponto relevante da teoria de Bobbio trata da composição do ordenamento jurídico. Nesse esteio, em todo o ordenamento, além de normas de conduta (aquelas que Bobbio classifica em proibitivas, permissivas e obrigatórias), há também as normas de estrutura ou de competência, sendo que estas últimas não prescrevem um comportamento, mas as condições e os procedimentos através dos quais emanam normas de condutas válidas.

\footnotetext{
15 BOBBIO, Norberto. Teoria do Ordenamento Jurídico. Trad. Ari Marcelo Solon. 2. ed. São Paulo: Edipro, 2020. p. 42.

$16 \quad$ Idem, p. 43.

17 Idem, p. 45.
} 


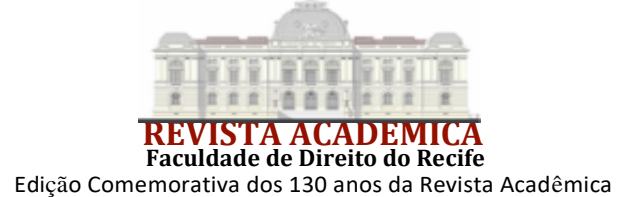

Contudo, Bobbio apresenta como elementos indispensáveis à diferenciação de um ordenamento qualquer de um ordenamento jurídico a presença de quatro características que, em conjunto, tornam jurídico determinado conjunto de normas: a) unidade: se as normas correlacionam-se e formam um conjunto; b) coerência: se este conjunto de normas se organiza de modo hierarquizado e constitui um sistema que rechaça as antinomias normativas; c) completude: se o conjunto de normas regula satisfatoriamente os comportamentos exigidos e se há mecanismos de solução de lacunas; e 4) se o ordenamento se relaciona com outros ordenamentos jurídicos e se há normas de reenvio de um a outro.

Estes quatro elementos traduzem os principais problemas que a sua teoria do Direito não conseguiu explicar, do ponto de vista da norma jurídica, bem como são a espinha dorsal da sua Teoria do Ordenamento Jurídico.

Contudo, uma análise mais aprofundada destes quatro problemas tratados por Bobbio será realizada na terceira parte do presente trabalho, quando serão contrapostos a natureza, características e especificidades da Lex Mercatoria aos critérios formadores de um ordenamento jurídico, de modo a se analisar se os usos e costumes do comércio internacional configuram ou não Direito.

\section{A LEX MERCATORIA: OS USOS E COSTUMES QUE REGEM O COMÉRCIO INTERNACIONAL. UMA REGULAÇÃO JURÍDICA DO COMÉRCIO INTERNACIONAL?}

A Lex Mercatoria é um tema de relevo para o Direito Internacional Privado, especialmente no que tange ao comércio internacional. Este ramo do Direito, embora tenha maximizado sua relevância após as grandes guerras que macularam o século $\mathrm{XX}^{18}$, com a criação de diversos mecanismos internacionais e a multiplicação dos Estados nacionais - tanto em razão da independência de diversas ex-colônias, tanto pela divisão de países e impérios, como o Austrohúngaro e o Otomano -, historicamente é objeto de interesse acadêmico. Já em 1914, Odilon Nestor considerava o Direito Internacional Privado uma sciencia "tão difficil quanto deveras attrahente", enquanto relatava a dificuldade de conceituar esse "departamento do direito [...] immensamente discutido ${ }^{19}$ ".

A exemplo de considerável parte dos estudos relativos ao campo do Direito, o debate acerca da Lex Mercatoria começa com a sua difícil conceituação e nomenclatura, marcada por "uma carga de idealização histórica muito forte e arraigada no imaginário das pessoas, [e] carrega uma herança doutrinária que precisou ser debatida e confrontada ${ }^{20 "}$.

Desse modo, mostra-se necessário em alguns casos, de modo a delimitar o tema abordado, conceituar o objeto em estudo, e, eventualmente caracterizá-lo, haja vista que a compreensão, enquanto processo de conhecimento, está ligada a esquemas cognitivos internalizados, na medida em que só é possível identificar algo como sendo determinada coisa a partir de categorias ou

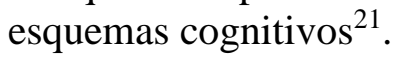

${ }^{18}$ IP, Eric C. Globalization and the future of the law of the sovereign state. I Con, v. 8, n. 3, p. 636-655, 2010.

19 NESTOR, Odilon. Direito Internacional Privado. Execução das sentenças estrangeiras e os efeitos dessas sentenças fora do Estado onde foram proferidas. Revista Acadêmica da Faculdade de Direito do Recife, Recife, v. 22, n. 1, 1914. Disponível em: https://periodicos.ufpe.br/revistas/ACADEMICA/article/view/242675/33197. Acesso em: 10 set. 2021.

20 COSTA, Cynara de Barros. Direito Transnacional do Comércio: Uma teoria afirmativa da natureza jurídica das normas do comércio transnacional, 2016. Tese (Doutorado em Direito) - Universidade Federal de Pernambuco, Recife, 2016. f. 19.

${ }^{21}$ MARCUSCHI, Luiz Antônio. Processos de compreensão. Produção textual, análise de gênero e compreensão. São Paulo: Parábola 2008. p. 228. Interessante também o seguinte raciocínio do autor a respeito: “Assim, a percepção é, em boa medida, guiada e ativada pelo nossos sistemas socioculturais internalizados ao longo da vida (...) Eu não vejo uma cadeira e sim um objeto que é percebido pelas condições cognitivas internalizadas e que então é 
Parte da literatura sobre o tema delineia a Lex Mercatoria como uma herança de leis deixada por uma comunidade mercantil remota ${ }^{22}$, autônoma, cosmopolita e a-nacional, que regula o comércio entre povos desde a Antiguidade ou o longínquo período das feiras medievais e mercados espalhados pela Europa. Todavia, essa imagem é questionada por outra parte da doutrina pertinente, que defende que a existência de uma Lex Mercatoria nesses moldes aparenta ser mais uma questão de crença popular do que rigor científico ${ }^{23}$.

O corpo de leis do comércio utilizado até o declínio da Idade Média é nomeado por alguns escritores como antiga Lex Mercatoria, enquanto a "reencarnação" ou "renascimento" desta regulação comercial a partir da universalização do comércio internacional com o advento da Idade Contemporânea é chamada, a depender do teórico, de moderna Lex Mercatoria, Nova Lex Mercatoria, Novíssima Lex Mercatoria ou Verdadeira Lex Mercatoria ${ }^{24}$. Cada um dos termos apresentados, temperados por uma preposição diferenciadora (nova, novíssima, verdadeira, dentre outras), traz consigo uma carga de definição específica. Mais adiante serão suscintamente abordadas as contribuições ao debate trazida por cada nova "geração" da Lex Mercatoria.

O certo é que essa diversidade de termos semelhantes utilizados para tratar de possíveis variações ou evoluções da Lex Mercatoria, embora necessária do ponto de vista da essência (haja vista a dinâmica do comércio transnacional ${ }^{25}$ hoje ser completamente distinta do comércio entre os diferentes povos na Antiguidade ou na Idade Média, quando sequer havia a figura do Estadonação como estruturado hodiernamente), acabaram por criar uma constante confusão conceitual, fazendo com que muitos doutrinadores buscassem termos mais adequados à definição desse conjunto normativo, por vezes apontando a própria expressão "Lex Mercatoria" como inapropriada. Contudo, os vários processos de significação e ressignificação do termo serviram mais para evocar uma genealogia para a Lex Mercatoria do que para atender às necessidades acadêmicas e práticas do comércio transacional ${ }^{26}$.

À parte a crítica à nomenclatura, para uma melhor compreensão, mostra-se necessário demonstrar a conceituação feita por alguns teóricos do assunto. Um dos maiores exponenciais do Direito Internacional Privado no Brasil, Luiz Olavo Baptista define a Lex Mercatoria como "o conjunto de princípios, instituições e regras com origem em diversos focos, e que se caracterizam por serem inspiradas e voltadas aos relacionamentos dos operadores do comércio internacional ${ }^{27}$ ". O certo é que tradicionalmente consideradas como soft law, a Lex Mercatoria influenciou "diversos ordenamentos jurídicos estatais ao longo da Idade Moderna, num movimento de 'renascença' da importância conferida às práticas mercantis adotadas pelos agentes do comércio

identificado como cadeira. Se eu nunca vi cadeiras nem construí a experiência de cadeira, não reconheço uma cadeira quando alguém me põe um objeto desse tipo pela frente. A cadeira, na sua condição de um objeto físico e cultural para determinada função ou ação cotidiana - por exemplo, sentar -, não é um dado dos sentidos. mas uma elaboração cognitiva. E assim se dá com todo o processo de compreensão".

22 HATZIMIHAIL, Nikitas E. The Many Lives and faces of Lex Mercatoria: History as genealogy in international business law. Law and contemporary problems, v. 71, n. 3, p. 169-190, 2008. No original: Historical imagery plays an important part in the lex mercatoria discourse. Claiming that mercantile rules derive from a merchant community and transcend time and space has been, in fact, a phenomenon older than lex mercatoria itselfperhaps as old as the assertion of some scholarly or institutional autonomy for commercial affairs. Disponível em: https://scholarship.law.duke.edu/cgi/viewcontent.cgi?article=1484\&context=lcp. Acesso em: 22 set. 2021.

23 COSTA, Cynara, de Barros. A verdadeira Lex Mercatoria: o direito além do Estado: um estudo sobre as antigas e novas teorias da Lex Mercatoria. Dissertação (Mestrado em Direito) - Universidade Federal de Pernambuco, Recife, 2011. f. $13-14 . \quad$ Disponível em: https://repositorio.ufpe.br/bitstream/123456789/4772/1/arquivo6701_1.pdf. Acesso em: 22 set. 2021.

24 Idem, p. 27-28.

25 Para os fins do presente artigo, os termos "internacional" e "transnacional" são utilizados como sinônimos.

26 COSTA, Cynara de Barros. Direito Transnacional do Comércio: Uma teoria afirmativa da natureza jurídica das normas do comércio transnacional, 2016. Tese (Doutorado em Direito) - Universidade Federal de Pernambuco, Recife, 2016. f. 20.

27 BAPTISTA, Luiz Olavo. Contratos Internacionais. São Paulo: Lex Magister, 2011. p. 63. 


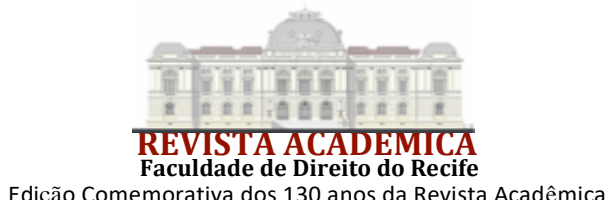

global $^{28} "$

Interessante definição é trazida pela professora Eugênia Barza, que define a Lex Mercatoria como os usos e costumes do comércio, que formam um conjunto normativo estruturado como um sistema reticular, mas que não impõe oposição aos ordenamentos nacionais, mas atua complementando estes $^{29}$. Já o professor Sylvio Loreto contribui com o debate ao lecionar que a Lex Mercatoria "é fonte normativa para buscar a ordem pública internacional em matéria de comércio internacional ${ }^{30}$ ".

A existência de uma Nova Lex Mercatoria, sucessora das antigas normas do comércio entre os povos, foi defendida, dentre outros, por Berthold Goldman, que defendeu seu caráter de fonte do direito, e que cada uma de suas normas seria uma norma legal por si mesma. Nesse sentido, seria o conjunto das relações econômicas internacionais ${ }^{31}$. Na seara acadêmica contemporânea, a visão defendida por Goldman é uma das pioneira a estudar a Lex Mercatoria, defendendo que esta seria a manifestação de uma lei sem o Estado, e que estaria assumindo características próprias de um ordenamento jurídico.

Por vezes o posicionamento de Goldman é apontado como "romantizado" e carente de embasamento documental e teórico que sustente tanto a hipótese da existência de um corpo uno de leis de comércio no passado (antiga Lex Mercatoria) e que haveria nos tempos atuais um sistema jurídico a-nacional que regularia o comércio transnacional.

Com efeito, Goldman defendia ainda uma separação radical entre a Lex Mercatoria e os ordenamentos nacionais, afirmando que o caráter volúvel daquela, bem como sua natureza costumeira e espontânea, não poderiam ser inseridos numa ordem jurídica nacional. Assim, o autor exclui a possibilidade de haver qualquer fonte estatal ou interestatal na Lex Mercatoria ${ }^{32}$. Esta seria, portanto, uma lei sem o Estado.

Outro expoente que tratou da Nova Lex Mercatoria foi Clive Schimitthoff, que a considerou um fenômeno totalmente novo em comparação àquela Lex Mercatoria medieval, e que o fenômeno contemporâneo voltaria a apresentar as características da sua antiga versão, ou seja, funcionaria como uma ordem não-sistemática, complexa e multiforme. Nesse esteio, o autor aponta que as fontes da Nova Lex Mercatoria seria a legislação internacional e o costume internacional, que ensejaria um efeito unificador das relações de comercio transnacional ${ }^{33}$.

Contudo, o maior diferencial de Schimitthoff em relação a Goldman diz respeito à admissão por aquele da ideia de que é possível haver uma contribuição tanto de fontes estatais como de fontes não estatais para a formação da Nova Lex Mercatoria.

Gunter Teubner acrescenta ao debate sobre a Lex Mercatoria dois elementos interessantes: a Teoria do Jogos e o referencial autopoiético de Niklas Luhmann. A conjunção de tais fatores deu origem à chamada Novíssima Lex Mercatoria.

Para este autor, o Direito seria então um jogo, que em paralelismo e acomunado com vários outros movimentos tenta construir um conceito pós-estruturalista do Direito, afastando deste

${ }^{28}$ BÔAVIAGEM, Aurélio Agostinho da. O Estado como parte contratante nas relações comerciais internacionais uma releitura do exercício da soberania à luz da "nova nova" Lex Mercatoria. Revista de Direito Internacional Econômico e Tributário, Brasília, v. 13, n. 2, p. 364-382, 2018.

29 BARZA, Eugênia Cristina Nilsen Ribeiro; GUIMARÃES, Marcelo Cesar. Os Princípios da Haia sobre a Escolha da Lei Aplicável aos Contratos Comerciais Internacionais, Fortaleza: UNIFOR. In: CONGRESSO BRASILEIRO DE DIREITO INTERNACIONAL. CODIFICAÇÃO DO DIREITO INTERNACIONAL, 13., 2015. v. 1, p. 1-12.

${ }^{30}$ LORETO, Sylvio; BARBOSA, Pedro Henrique de Faria. O mito de Jano: as duas faces da ordem pública no Direito Internacional Privado. Revista Interação, Santa Maria, v. 12, n. 12, p. 103-118, 2017.

31 COSTA, Cynara, de Barros. A verdadeira Lex Mercatoria: o direito além do Estado: um estudo sobre as antigas e novas teorias da Lex Mercatoria. Dissertação (Mestrado em Direito) - Universidade Federal de Pernambuco, Recife, 2011. f. 33. Disponível em: https://repositorio.ufpe.br/bitstream/123456789/4772/1/arquivo6701_1.pdf. Acesso em: 22 set. 2021.

32 Idem.

33 Idem, p. 38-39.

SILVA, Madson Douglas Xavier da; BÔAVIAGEM, Aurélio Agostinho da. A LEX MERCATORIA ENQUANTO DIREITO: UMA ANÁLISE DA NATUREZA DAS NORMAS QUE REGEM O COMÉRCIO INTERNACIONAL À LUZ DA TEORIA DO ORDENAMENTO JURÍDICO DE NORBERTO BOBBIO. Revista Acadêmica da Faculdade de Direito do Recife - ISSN: 24482307, Edição Comemorativa dos 130 anos da Revista Acadêmica, p. 178-198. Nov. 2021. ISSN 2448-2307. <Disponível em: https://periodicos.ufpe.br/revistas/ACADEMICA/article/view/252575> 


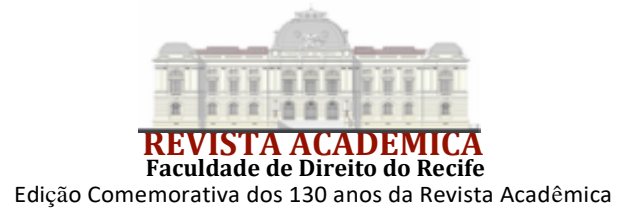

o caráter estático conferido pelo positivismo e conferindo-o uma dinamicidade típica dos jogos. Assim, enxergar o Direito como um jogo é enxerga-lo como discurso, como disciplina e como um sistema ${ }^{34}$.

Nesse esteio, Teubner, ao lançar sobre a Lex Mercatoria a autopoiese de Luhmann, defende que o Direito, assim como outros sistemas, como a política ou a economia, está fechado e aberto ao mesmo tempo, fazendo com que comporte paradoxos de maneira pacífica, culminando assim com uma unidade conceitual ${ }^{35}$. Esta é a ideia de reentrada, alinhada à percepção de sistema como moldura, que, no lugar de limitar o âmbito interno, passa a fazer parte do próprio território, na fronteira com outros sistemas ${ }^{36}$.

Uma das mais recentes contribuições para o debate da Lex Mercatoria foi dada por Ralph Michaels, que inaugurou a chamada Verdadeira Lex Mercatoria. A ideia central trazida pelo referido autor é que a Lex Mercatoria constitui um sistema jurídico autônomo, independente e paralelo aos regimes jurídicos nacionais. Com efeito, defende ainda que a existência de uma Lex Mercatoria como um corpo normativo independente só é possível a partir da perspectiva da Teoria dos Sistemas. Assim, aquilo que os teóricos apontaram anteriormente como uma Lex Mercatoria desde a Antiguidade até a contemporaneidade não seria verdadeiramente uma lei do comércio ${ }^{37}$.

A contribuição mais evidente de Michaels foi considerar que a Lex Mercatoria caminha para se tornar um completo e complexo sistema jurídico, capaz de se institucionalizar através da arbitragem internacional, baseada inclusive num conjunto de normas codificadas, embora o próprio autor entenda que a Lex Mercatoria ainda não atingiu esse nível de institucionalização, sendo este um processo para o futuro. Assim, estaria em processo de nascimento uma lei além do Estado $^{38}$.

Autores mais recentes, como Cynara de Barros Costa, defendem que Lex Mercatoria já se desenvolveu ao ponto de se tornar um autêntico sistema normativo de natureza jurídica. A referida autora, inclusive, abandona a nomenclatura "Lex Mercatoria" e nomeia este fenômeno de Direito Transnacional do Comércio ${ }^{39}$. Como o próprio nome sugere, a professora chega à conclusão de que a Lex Mercatoria é, de fato, Direito, sob a perspectiva pluralista, sistematicamente organizado, dotado de fontes, regras e mecanismos de processamento e decisões jurídicas, no âmbito dos Tribunais Arbitrais.

O fato é que a Lex Mercatoria, até pela sua fluidez e desvinculação legal, e por apresentar mandamentos em certa medida indefinidos que servem a sanar invitáveis problemas do comércio internacional para o quais não há regramento, quando aplicada pelo intérprete para reger atos de

34 Idem, p. 68-69.

35 Pertinente a contribuição da professora Eugênia Barza: "com essa interpenetração das estruturas empresariais, a interconexão dos sistemas financeiros e a formação dos grandes blocos regionais convertem-se em efetivos centros de poder, de sorte que o sistema político, representado pelo Estado-Nação, deixa de ser o locus natural de organização da sociedade. Assim, em vez de uma ordem soberanamente produzida, tem-se uma ordem crescentemente recebida dos agentes econômicos, tratando-se de uma ordem cada vez mais auto-organizada e autorregulada. Esta ordem tende a transcender os limites e controles impostos pelo Estado, a substituir a política pelo mercado como instância máxima de regulação social, a adotar as regras flexíveis da lex mercatoria ao invés das normas do direito positivo". BARZA, Eugênia Cristina Nilsen Ribeiro; GUIMARÃES, Marcelo Cesar. A atuação empresarial transnacional: conceito, formas de atuação, efeitos e perspectivas para a regulamentação. Revista Acadêmica da Faculdade de Direito do Recife, Recife, v. 87, n. 2, p. 49-71, 2015.

36 Idem, p. 71.

37 Idem, p. 83-85.

38 MICHAELS, Ralf. Globalization and Law: Law Beyond the State. Durhan: Law and Society Theory (Banakar and Travers eds., $\quad 2013 . \quad$ Dorthcoming), $\quad 2$ Disponível https://scholarship.law.duke.edu/cgi/viewcontent.cgi?article=5540\&context=faculty_scholarship. Acesso em: 24 set. 2021.

39 COSTA, Cynara de Barros. Direito Transnacional do Comércio: Uma teoria afirmativa da natureza jurídica das normas do comércio transnacional, 2016. Tese (Doutorado em Direito) - Universidade Federal de Pernambuco, Recife, 2016. 


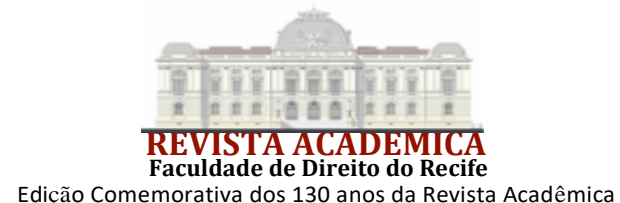

Edição Comemorativa dos 130 anos da Revista Acadêmica

comércio, funciona como típico conceito jurídico indeterminado ${ }^{40}$.

De modo interessante, a Lex Mercatoria, do ponto de vista sistêmico abordado diferenciadamente por Teubner, Michaels e Costa, se aplicada pelos ordenamentos internos, pode emprestar "previsibilidade e segurança, previsibilidade por submeter a um mesmo regime os envolvidos no comércio internacional, e segurança jurídica por sanções efetivas oriundas dos tribunais arbitrais e estatais ${ }^{41}$ ".

\section{UMA ANÁLISE DA LEX MERCATORIA À LUZ DA TEORIA DA NORMA JURÍDICA: UNIDADE, COERÊNCIA, COMPLETUDE E AS RELAÇÕES ENTRE OS ORDENAMENTOS JURÍDICOS}

Um esforço inicial necessário à análise se a Lex Mercatoria constitui ou não uma ordem jurídica é, obviamente, delinear o que se convencionou chamar de ordenamento jurídico. Somente com o estabelecimento de um parâmetro é possível exercitar a comparação, pois, se duas coisas são semelhantes, uma delas pode tornar-se signo da outra, e vice-versa. Dentro desse fenômeno da semiótica hermética, o signo analisado de forma isolada se limita a um elemento hermético, de significado único, enquanto que aplicado dentro de um contexto, passa à possibilidade de dispor de múltiplos significados ${ }^{42}$.

Delimitar o conceito de Direito e diferenciá-lo de outras ciências é um debate acadêmico há muito praticado, que albergou inclusive a discursão se o Direito seria ou não uma ciência. Nessa perspectiva, o Direito, ao contrário das ciências naturais - que deixam "a pessoa do sujeito cognoscente fora do processo de conhecimento graças a uma objetividade específica" -, enquanto ciência humana, necessita delimitar muito bem o "conglomerado de elementos normativos e factuais" que o distingue ${ }^{43}$.

Adentrando na análise do que é o Direito, Friedrich Müller elaborou a sua Teoria Estruturante do Direito, que estuda os elementos particulares que caracterizam esta ciência, e delimita que não se pode compreendê-la a partir de um conceito ideal absoluto, mas só mediante uma racionalidade verificável e discutível no âmbito da aplicação da norma ${ }^{44}$.

Em suma, o fator que torna jurídica determinada norma ou corpo de normas é a existência de alguns elementos específicos que distinguem o Direito de outros sistemas normativos desprovidos de juridicidade. Contudo, esta afirmação não serve à finalidade de definir o Direito, mas funciona como uma premissa a ser complementada, um receptáculo a ser preenchido com um conteúdo, pois o questionamento lógico que se segue é: quais são estes elementos específicos que tornam jurídica determinada norma ou conjunto de normas?

Este questionamento pode ser aplicado à análise da própria Lex Mercatoria: este conjunto de usos e costumes que regem o comércio internacional é dotado de um caráter distintivo que o torne Direito? Quais seriam os elementos que diferenciariam estas normas e sanções adotadas consuetudinariamente pelo comércio das normas e sanções típicas da economia, da geopolítica, ou das relações internacionais, por exemplo? Quais seriam os elementos de "juridicização" da Lex Mercatoria?

${ }^{40}$ Sobre conceito jurídico indeterminado, há interessante debate em: KRELL, Andreas. A recepção das teorias alemãs sobre "conceitos jurídicos indeterminados" e o controle da discricionariedade no Brasil. Interesse Público, Porto Alegre, v. 23, p. 21-49, 2004.

41 BÔAVIAGEM, Aurélio Agostinho da. Sobre princípios dos contratos internacionais de comércio. Revista Acadêmica da Faculdade de Direito do Recife, Recife, v. 88, n. 2, p. 63-81, 2016.

42 ECO, Humberto. Interpretação e superinterpretação. São Paulo: Martins Fontes, 1997. p. 55-56.

43 MÜLLER, Friedrich. Teoria jurídica estruturante. São Paulo: Revista dos Tribunais, 2008. p. 14.

44 MÜLLER, Friedrich. O novo paradigma do direito: introdução à teoria e metódica estruturantes. 3 ed. São Paulo: Revista dos Tribunais, 2013. p. 19. 
Como analisado na primeira parte do presente trabalho, Norberto Bobbio responde aos questionamentos quanto aos fatores que caracterizam o Direito a partir da perspectiva do ordenamento jurídico. Desse modo, o problema da definição do Direito se torna um problema de definição de um ordenamento jurídico, diferenciado dos ordenamentos não jurídicos.

Nesse sentido, de acordo com a Teoria do Ordenamento Jurídico, os caracteres diferenciadores do ordenamento jurídico são quatro: unidade, coerência, completude e relacionamento com outros ordenamentos jurídicos. Assim, de modo a aferir se há a constituição de um ordenamento jurídico, e, consequentemente, se há natureza de Direito, resta necessário averiguar se os quatro elementos referidos por Bobbio encontram-se presentes na Lex Mercatoria.

\subsection{A UNIDADE DO ORDENAMENTO JURÍDICO}

O primeiro elemento caracterizador de um ordenamento jurídico é a unidade. Para Bobbio, é necessário haver uma delimitação que permita a individualização do ordenamento e sua diferenciação de outros ordenamentos. Assim, não é possível falar de ordenamento jurídico se não o considerarmos algo unitário. Dito isso, o jurista italiano insere nesse ponto o debate sobre as fontes do Direito, num exercício de "regressão", posto que, se identificadas as fontes que originam determinado ordenamento jurídico, se identificará sua individualização. Nesse contexto, Bobbio afirma que não é possível que um ordenamento possua apenas uma única fonte, uma vez que a necessidade de regras de conduta de uma sociedade é tamanha que nenhum poder ou órgão tem condições de satisfazê-la isoladamente ${ }^{4546}$.

Com efeito, para suprir esta demanda, o poder supremo recorreria a duas formas de produção de normas: 1) a recepção de normas já prontas, originadas em outros ordenamentos diversos e precedentes, e 2) a delegação do poder de produção normativa a órgãos inferiores. Quanto à primeira forma (recepção), esta não é visível no âmbito da Lex Mercatoria, uma vez que, por constituir um corpo de lei consuetudinárias e em certa medida carente de codificação ${ }^{47}$, não haveria "normas já prontas" passíveis de recepção. Já em relação à segunda forma (delegação), Bobbio suscita o debate quanto às normas consuetudinárias, que mais interessam ao presente trabalho, na medida em que a Lex Mercatoria é, como já afirmado, essencialmente um conjunto de normas costumeiras.

Neste debate das fontes, Bobbio aparenta indicar que não é suficiente que uma norma seja criada pelo costume, mas que tal possibilidade tenha arcabouço em um poder supremo, que autorize e reconheça como jurídica a norma consuetudinária. Assim, para que o costume crie uma norma jurídica, é necessário que tenha havido a delegação de tal possibilidade pelo poder supremo.

45 BOBBIO, Norberto. Teoria do Ordenamento Jurídico. Trad. Ari Marcelo Solon. 2. ed. São Paulo: Edipro, 2020. p. 49-50.

46 Pertinente colacionar o seguinte trecho de Virgílio Afonso da Silva quanto à unidade do sistema jurídico, aqui analisando a unidade da Constituição: "quando se fala em unidade da constituição [...] normalmente se quer dizer simplesmente que o intérprete deve considerar as normas constitucionais não como isoladas e dispersas, mas como preceitos integrados, evitando-se, assim, contradições internas no seio da constituição". Ver: SILVA, Virgílio Afonso da. Interpretação constitucional e sincretismo metodológico. In: Interpretação constitucional. São Paulo: Malheiros, 2005. p.115-143.

47 Lauro Gama Jr. aponta que os Princípios do UNIDROIT seriam uma resposta à carência de codificação da Lex Mercatoria, na esteira do "movimento codificador, [que] interessou-se pelo fenômeno da diversidade legislativa no plano internacional". O autor menciona que há uma tentativa de uniformização de um Direito Internacional Privado: "Tradicionalmente, o direito internacional privado contempla a solução de conflitos de leis no espaço mediante a indicação, pela norma conflitual, do direito aplicável à relação jurídica. Contudo, tais conflitos também podem ser solucionados pela criação de um direito uniforme, que elimine total ou parcialmente a diversidade legislativa mediante o estabelecimento de normas materiais ou substantivas sobre determinada matéria". Apenas a título de nota, o presente autor acredita que uma unificação codificada do Direito Internacional Privado é uma ideia ainda bastante insólita e distante. In: GAMA JR., Lauro. Contratos Internacionais à luz dos Princípios do UNIDROIT 2004: soft law, arbitragem e jurisdição. Rio de Janeiro: Renovar, 2006. p. 181. 


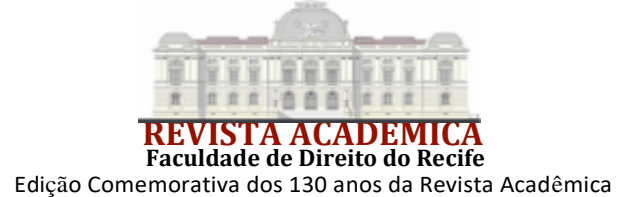

Neste aspecto, Bobbio parece se aproximar do critério de validade pressuposto, de $\mathrm{Alexy}^{48}$, bem como parece inserir no debate a justificação passo a passo como elemento de validade da norma, típico do método construtivo, na medida em que cada norma tem que ser justificada a cada novo ato mental (de conhecimento ou cognição), e deve sustentar uma linha corrente de pensamento ${ }^{49}$. Assim, não havendo um poder estabelecido e orientado dentro de uma estrutura normativa, não haveria uma "linha corrente de pensamento" na produção das normas consuetudinárias da Lex Mercatoria.

Ainda no âmbito do elemento da unidade do ordenamento, Bobbio discorre sobre o poder originário $^{50}$, que qualifica como "o ponto derradeiro de todas as normas [...] para além do qual não existe outro sobre o qual o ordenamento jurídico possa encontrar justificação. Este ponto de referência é necessário [...] para fundar a unidade do ordenamento ${ }^{51}$ ". Este ponto acerca da norma fundamental ou do poder originário do ordenamento - apontado por Bobbio como fundamento à unidade do ordenamento - é, provavelmente, um dos maiores problemas a ser resolvido no âmbito da Lex Mercatoria, e que não foi solucionado satisfatoriamente pelos teóricos do tema, especialmente pelos defensores da Lex Mercatoria enquanto Direito ${ }^{52}$. Nesse esteio, o problema da atribuição de uma norma fundamental à Lex Mercatoria parece ainda não resolvido pelos teóricos que defendem sua natureza jurídica.

Outro aspecto apontado por Bobbio que se relaciona diretamente com a ideia de norma fundamental e poder originário (e com o próprio conceito de Direito) diz respeito à força. Em que pese Bobbio objetar reduzir o Direito à força, pois é possível a existência de um poder que repouse exclusivamente no consenso, o autor considera indispensável que haja num ordenamento jurídico um poder coercitivo estabelecido, que submeta a todos sob sua jurisdição, pois, nesse sentido, "a força é um instrumento necessário ao poder. Isso não quer dizer que seja também o seu fundamento. A força é necessária para exercer o poder; não é necessária para justificá-10 ${ }^{53}$ ". Com efeito, a coercitividade exercida por um poder é indispensável ao Direito, uma vez que Bobbio aponta como impensável existir um ordenamento jurídico desvinculado do exercício da força coercitiva, isto é, sem um poder.

Desta feita, quanto ao primeiro elemento caracterizador de um ordenamento jurídico unidade - não é possível vislumbrar que a Lex Mercatoria cumpre tal característica, seja em razão do referido problema de suas fontes, seja na ausência de um poder que a ordene, ou de uma norma fundamental que a embase, ou pela ausência de coercitividade de suas normas.

\subsection{A COERÊNCIA DO ORDENAMENTO JURÍDICO}

48 ALEXY, Robert. Teoria dos Direitos Fundamentais. Trad. Virgílio Afonso da Silva. São Paulo: Malheiros, 2008. p. 62-63.

49 ALEXY, Robert. Teoria da Argumentação Jurídica. Trad. Zilda Hutchinson Schild Silva. São Paulo: Landy, 2001. p. 118-119.

50 Bobbio define o poder originário como "o conjunto de normas jurídicas que em um determinado momento histórico prevaleceram e instauraram um novo ordenamento jurídico". In: BOBBIO, Norberto. Teoria do Ordenamento Jurídico. Trad. Ari Marcelo Solon. 2. ed. São Paulo: Edipro, 2020. p. 72.

51 Idem, p. 52.

52 Na melhor doutrina consultada que advoga pela natureza jurídica da Lex Mercatoria (COSTA, Cynara de Barros. Direito Transnacional do Comércio: Uma teoria afirmativa da natureza jurídica das normas do comércio transnacional, 2016. Tese (Doutorado em Direito) - Universidade Federal de Pernambuco, Recife, 2016. A autora trata especificamente da análise da Teoria do Ordenamento Jurídico, de Norberto Bobbio, mas não adentra no debate quanto à "norma fundamental" ou o "poder originário" que embase a Lex Mercatoria, nem delineia se esta apresenta ou não os quatro elementos caracterizadores de um ordenamento jurídico, ora estudados.

53 BOBBIO, Norberto. Teoria do Ordenamento Jurídico. Trad. Ari Marcelo Solon. 2. ed. São Paulo: Edipro, 2020. p. 72.

SILVA, Madson Douglas Xavier da; BÔAVIAGEM, Aurélio Agostinho da. A LEX MERCATORIA ENQUANTO DIREITO: UMA ANÁLISE DA NATUREZA DAS NORMAS QUE REGEM O COMÉRCIO INTERNACIONAL À LUZ DA TEORIA DO ORDENAMENTO JURÍDICO DE NORBERTO BOBBIO. Revista Acadêmica da Faculdade de Direito do Recife - ISSN: 24482307, Edição Comemorativa dos 130 anos da Revista Acadêmica, p. 178-198. Nov. 2021. ISSN 2448-2307. <Disponível em: https://periodicos.ufpe.br/revistas/ACADEMICA/article/view/252575> 


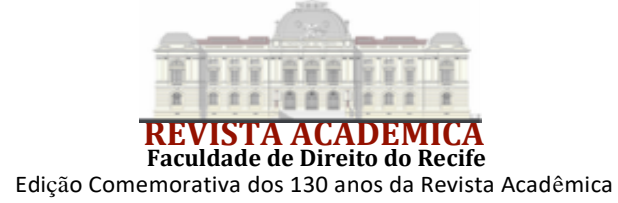

Adentrando ao segundo elemento caracterizador de um ordenamento jurídico, a coerência, Bobbio busca responder ao questionamento se o ordenamento jurídico, além de uma unidade, constitui também um sistema ${ }^{54}$, se se trata de uma unidade sistemática.

$\mathrm{O}$ autor inicia o debate quanto à coerência utilizando uma análise do conceito de sistema feita por Kelsen, que distingue os ordenamentos normativos em dois tipos: o estático e o dinâmico. No primeiro, as normas estão ligadas umas às outras por proposições dedutivas, ou seja, todas as leis são deduzidas de uma lei primeira, fundamental (o que reabre o discurso sobre a ausência de norma fundamental que embasaria a Lex Mercatoria), havendo, portanto, uma ligação entre as normas pelo conteúdo. Por outro lado, o sistema dinâmico configura-se pelas sucessivas delegações de poder da autoridade que o positivou para uma autoridade inferior, havendo uma ligação entre as normas não em relação ao conteúdo, mas em relação à forma.

Bobbio então afirma que, de acordo com a distinção adotada por Kelsen, os ordenamentos jurídicos são sistemas do segundo tipo, ou seja, dinâmicos. Por outro lado, revolvendo ao debate quanto à inexistência de um poder originário no âmbito da Lex Mercatoria, que possa impor o Direito, aplicá-lo coercitivamente, ou delegar poderes de criação de norma jurídica a hierarquia inferiores, este conjunto de normas do comércio internacional não se adequa a um sistema dinâmico, apresentando mais visivelmente aparência de um sistema estático, uma vez que suas normas se relacionam entre si essencialmente pela matéria, e não pela forma impelida por uma autoridade hierárquica.

Neste aspecto, a Lex Mercatoria, como sistema estático, está mais próxima da moral do que do Direito (sistema dinâmico), no sentido de que suas normas não contam com a coercibilidade típica da ordem jurídica. Com efeito, o descumprimento das normas da Lex Mercatoria, portanto, geram sanções de ordem econômica, não jurídicas, possuindo aquelas, no aspecto aqui abordado, a mesma coercibilidade das normas de moral. Para Bobbio, no que tange à coerência do ordenamento jurídico, a hierarquia é um fator central, no qual se estrutura o Direito e a sua produção, havendo uma interessante ligação com a forma lógica dos fatos ${ }^{55}$.

A ausência de estruturação da Lex Mercatoria pelo prisma da hierarquia ainda põe outra dificuldade relativa à coerência do ordenamento jurídico: a análise de solução das antinomias. Bobbio indica como necessário o dever da coerência dos ordenamentos jurídicos, que relacionase à disposição das normas de níveis hierarquicamente distintos, que se evidencia em três hipóteses possíveis.

A primeira hipótese de antinomia diz respeito ao conflito de normas de níveis distintos, que se desdobra em duas possibilidades: na primeira, a pessoa ou órgão autorizado a criar normas inferiores é obrigado a não produzir normas que se oponham à norma superior; na segunda, o julgador, ao se deparar com normas conflitantes, é obrigado a aplicar a norma superior. O debate quanto a esta hipótese de antinomia resta prejudicado, porquanto, como já analisado, não há uma estrutura hierárquica entre as normas da Lex Mercatoria.

A segunda hipótese diz respeito à antinomia de normas de mesmo nível, mas sucessivas no tempo. Assim, havendo conflito, o julgador deve aplicar a norma mais recente, permanecendo válida somente a segunda, em detrimento da primeira. De igual modo, este debate sobre a antinomia de normas de igual nível não é possível em relação à Lex Mercatoria, pois em razão de suas normas serem consuetudinárias, não é possível confirmar um parâmetro temporal que permita a resolução de antinomias pela aplicação da mais recente.

54 Bobbio define um sistema como "uma totalidade ordenada, isto é, um conjunto de entes entre os quais existe uma certa ordem. Para que se possa falar de ordem, é necessário que os entes constitutivos não estejam em relação apenas com o todo, mas também estejam em relação de coerência entre eles”. In: BOBBIO, Norberto. Teoria do Ordenamento Jurídico. Trad. Ari Marcelo Solon. 2. ed. São Paulo: Edipro, 2020. p. 77.

55 Sobre forma lógica dos fatos e hierarquia, ver: MEURER, Cesar. A Teoria correspondentista da Verdade. Apresentação e crítica lógico-semântica. Porto Alegre: FI, 2018. p. 15. 


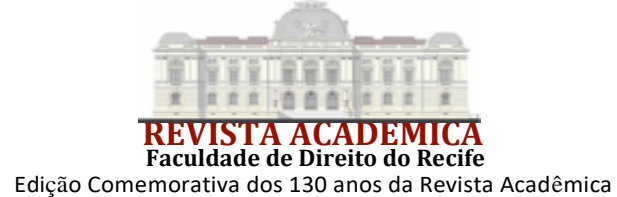

Já a terceira hipótese trata da antinomia de normas de mesmo nível e contemporâneas. Contudo, esta hipótese padece do mesmo problema da primeira, ante a impossibilidade de estabelecimento de hierarquia entre elas. Na verdade, o que se observa é que as normas da Lex Mercatoria, por serem essencialmente consuetudinárias, devem ser tratadas como se possuíssem o mesmo nível hierárquico, e por não ser possível estabelecer um marco temporal de origem, todas devem ser tratadas como contemporâneas.

Bobbio discorre sobre um problema a ser enfrentado quando há antinomias de normas de mesmo nível e contemporâneas: não existe nenhuma regra de coerência. Isso porque, diante do conflito, o julgador teria a necessidade de aplicar uma norma e a desaplicar outra, sem nenhum critério específico, ao passo que ambas as normas são válidas.

Nesse esteio, "a coerência não é condição de validade, mas é sempre condição para a justiça do ordenamento ${ }^{56}$ ". Assim, havendo duas normas contraditórias e válidas, o julgador teria à sua disposição um livre-arbítrio que violaria a duas exigências fundamentais que tendem a inspirar os ordenamentos jurídicos: a exigência da certeza e a exigência da justiça.

Sob a ótica da coerência, de igual modo a Lex Mercatoria não apresenta as características de um ordenamento jurídico.

\subsection{A COMPLETUDE DO ORDENAMENTO JURÍDICO}

O terceiro elemento caracterizador de um ordenamento jurídico é a completude ${ }^{57}$. Neste ponto, Bobbio aborda o problemas das lacunas. Para ele, um ordenamento completo é aquele onde não há caso que não possa ser solucionado com uma norma extraída do sistema. Nesse prisma, se não há no ordenamento nem a proibição nem a permissão de um determinado comportamento, se está diante de uma lacuna.

Embasando-se no Sistema de Savigny, Bobbio afirma que o conjunto das fontes do Direito forma um todo, que é destinado à todas as questões que se apresentam à sua apreciação. Assim, defende que o nexo entre a unidade e a completude do ordenamento jurídico é um fator indispensável que quase sempre foi negligenciado pela literatura jurídica. Com isso, a completude do ordenamento se alavanca para além de uma exigência, mas é, de fato, uma condição necessária para o funcionamento do sistema. Este é o dogma da completude.

Nesse esteio, a completude tradicionalmente se traduz em um duplo dever: o do julgador, que deve solucionar todas as controvérsias postas à sua análise; e que a solução dada tenha por base uma norma do próprio ordenamento.

O certo é que todo ordenamento jurídico possui lacunas ${ }^{58}$, caso contrário, não haveria a necessidade de prever meios de integração normativa, como a analogia e a equidade, por exemplo. Contudo, Bobbio expõe oportunamente uma crítica ao "fetichismo legislativo dos juristas" quanto à crença de que o Direito estatal seja completo, mencionando alguns teóricos da escola do direito livre e doutrinadores críticos ao estatismo jurídico, como François Gény, para quem o Direito é algo complexo e mutável, sendo impossível um indivíduo ou uma assembleia, de uma só vez, fixar todos os seus preceitos e satisfazer todas as exigências da vida jurídica ${ }^{59}$. Este ponto permite uma

56 BOBBIO, Norberto. Teoria do Ordenamento Jurídico. Trad. Ari Marcelo Solon. 2. ed. São Paulo: Edipro, 2020. p. 111.

57 Bobbio define a completude como "a propriedade pela qual um ordenamento jurídico tem uma norma para regular qualquer caso. Dado que a ausência de uma norma se chama, com frequência, de 'lacuna' (em um dos sentidos do termo 'lacuna'), 'completude' significa 'ausência de lacunas"'. In: BOBBIO, Norberto. Teoria do Ordenamento Jurídico. Trad. Ari Marcelo Solon. 2. ed. São Paulo: Edipro, 2020. p. 113.

58 "O Direito não é lacunoso, mas há lacunas": expressão atribuída a Maria Helena Diniz. In: TARTUCE, Flávio. Manual de Direito Civil. 10. ed. Rio de Janeiro: Forense: São Paulo: Método, 2020. p. 9. Volume único.

59 BOBBIO, Norberto. Teoria do Ordenamento Jurídico. Trad. Ari Marcelo Solon. 2. ed. São Paulo: Edipro, 2020. p. 122. 


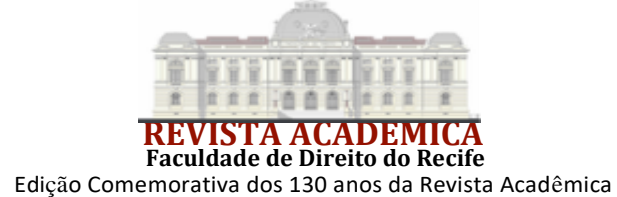

análise mais aproximada com a Lex Mercatoria, uma vez que Bobbio delineia os estudos de alguns teóricos quanto ao direito consuetudinário, ou seja, um direito de origem não legislativa, sendo a Lex Mercatoria essencialmente costumeira.

Contudo, expõe uma corrente contrária à escola do direito livre (que entendia desnecessária ao ordenamento jurídico o elemento de completude), a dos tradicionalistas, que sustentou que a existência de um Direito não atrelado ao Estado seria uma reencarnação do direito natural e que romperia a barreira do princípio da legalidade, abrindo as portas ao arbítrio e ao anarquismo. A contribuição dos teóricos desta corrente, nomeados por Bobbio de "positivistas estritos", foi o enunciado do espaço jurídico vazio.

Em suma, o enunciado sintetiza que

Toda norma jurídica representa uma limitação à livre vontade humana; com exceção da esfera regulada pelo direito, o homem é livre para fazer o que quiser. O âmbito de atividade de um homem pode, portanto, considerar-se dividido, do ponto de vista do direito, em dois compartimentos: aquele em que é vinculado por normas jurídicas e que podemos chamar de espaço jurídico cheio, e aquele em que é livre, e que podemos chamar de espaço jurídico vazio. Ou há o vínculo jurídico, ou há absoluta liberdade [...] Não existe nenhum espaço para as lacunas do direito ${ }^{60}$.

O que se extrai é que a Lex Mercatoria, até por se constituir um conjunto esparso de normas consuetudinárias, com nenhuma ou pouquíssima codificação ${ }^{61}$, não permite uma clara análise quanto à extensão de sua regulamentação ou sobre as eventuais lacunas que este corpo de normas apresenta. Neste aspecto, a codificação do Direito ou a tradução deste na jurisprudência aparenta ser um elemento necessário à identificação de lacunas no ordenamento.

Não havendo uma satisfatória codificação da Lex Mercatoria, nem sua positivação e/ou absorção pelos ordenamentos estatais (parte da doutrina especializada se posiciona inclusive contra a codificação da Lex Mercatoria pelo Direito estatal, sob pena de desnaturá-la, como defende Goldman $^{62}$ ), nem havendo uma consolidada jurisprudência sobre a matéria, posto que é a arbitragem internacional que mais se debruça sobre a aplicação da Lex Mercatoria, e os laudos arbitrais via de regra são sigilosos ${ }^{63}$, resta impossível averiguar neste conjunto uma completude sistêmica.

Ainda em relação às lacunas, o que se observa na Lex Mercatória é um movimento oposto, no seguinte sentido: um dos aspectos dos contratos internacionais é a possibilidade de escolha do Direito aplicável à sua regência, que pode ser o do país do vendedor, do comprador, do país onde a obrigação deve ser satisfeita ou o de um país terceiro livremente indicado pelas partes, sendo que, de todo modo, esta escolha está limitada por preceitos de ordem pública ${ }^{64}$. Com efeito, os contratos de comércio internacional via de regra não elegem como regulação exclusiva a Lex Mercatoria (até em razão de suas limitações práticas, ora analisadas), mas sim o Direito de determinado país. Contudo, a prática demonstra que estes contratos comumente preveem que

60 Idem, p. 124

61 Há quem advogue que os princípios do UNIDROIT sejam uma tentativa de codificação da Lex Mercatoria. Vide nota 44.

62 COSTA, Cynara, de Barros. A verdadeira Lex Mercatoria: o direito além do Estado: um estudo sobre as antigas e novas teorias da Lex Mercatoria. Dissertação (Mestrado em Direito) - Universidade Federal de Pernambuco, 2011 f. 32-35. Disponível em: https://repositorio.ufpe.br/bitstream/123456789/4772/1/arquivo6701_1.pdf. Acesso em: 22 set. 2021.

${ }^{63}$ VIANNA, Sâmila Nunes. O sistema de precedentes na arbitragem internacional: perspectivas na jurisprudência arbitral comercial. Dissertação (Mestrado em Direito) - Universidade Federal de Pernambuco, Recife, 2021.

${ }^{64}$ BÔAVIAGEM, Aurélio Agostinho da. A ordem pública: limite da autonomia da vontade na escolha da lei aplicável. Anuário dos Cursos de Pós-Graduação em Direito (UFPE), Recife, v. 16, p. 25-36, 2006.

SILVA, Madson Douglas Xavier da; BÔAVIAGEM, Aurélio Agostinho da. A LEX MERCATORIA ENQUANTO DIREITO: UMA ANÁLISE DA NATUREZA DAS NORMAS QUE REGEM O COMÉRCIO INTERNACIONAL À LUZ DA TEORIA DO ORDENAMENTO JURÍDICO DE NORBERTO BOBBIO. Revista Acadêmica da Faculdade de Direito do Recife - ISSN: 24482307, Edição Comemorativa dos 130 anos da Revista Acadêmica, p. 178-198. Nov. 2021. ISSN 2448-2307. <Disponível em: https://periodicos.ufpe.br/revistas/ACADEMICA/article/view/252575> 
eventuais lacunas contratuais ou do Direito estatal escolhido devem ser supridas pelos usos e costumes do comércio ${ }^{65}$.

Ou seja, a Lex Mercatoria tem servido mais como elemento de preenchimento de eventuais lacunas do Direito estatal do que de regulação exclusiva do comércio internacional.

\subsection{AS RELAÇÕES ENTRE OS ORDENAMENTOS JURÍDICOS}

O quarto e último elemento caracterizador de um ordenamento jurídico constitui-se nas relações entre os diversos ordenamentos. Enquanto os três elementos iniciais tratam de problemas intrínsecos aos ordenamentos, este último se debruça sobre um viés extrínseco.

A necessidade do debate quanto a este elemento surge da complexidade ${ }^{66}$ e multiplicidade dos ordenamentos jurídicos que regem as relações humanas, uma vez que atualmente há inúmeras nações, que tendem a expressar cada uma um ordenamento. Além disso, onde existe um poder soberano, existe um Direito, e sendo por definição o poder soberano independente de qualquer outro poder soberano, cada Direito constitui um ordenamento autônomo ${ }^{67}$.

Nesse sentido, Bobbio relembra a figura da pirâmide normativa para demonstrar que as normas de um ordenamento podem ser dispostas em ordem hierárquica, e que nada impede que os ordenamentos estejam entre si numa relação de superior para inferior. Assim, uma pirâmide que nasce no interior de um ordenamento pode prolongar-se para fora deste, fazendo surgir uma relação de subordinação entre os ordenamentos. A figura da pirâmide é aqui utilizada para demostrar a possibilidade de um ordenamento se sobrepor a outro.

Com efeito, o jurista italiano aponta que, numa primeira classificação, as relações entre os ordenamentos pode ser realizadas com base no grau de validade que eles têm um em relação ao outro, distinguidas em relações de coordenação e de relações de subordinação. As primeiras existem entre Estados soberanos que estão no mesmo plano, marcadas por um regime pactuário, onde as regras de coexistências são o produto de uma autolimitação recíproca de poder. Já as segundas existem entre os Estados e os ordenamentos sociais parciais, como os sindicatos e as igrejas, por exemplo, cuja validade deriva do reconhecimento do Estado ${ }^{68}$.

Tema recorrente entre os estudiosos da Lex Mercatoria, a aceitabilidade desta como norma jurídica paritária pelos ordenamentos estatais é comumente rechaçada, especialmente pelo Judiciários internos, que resistem em reconhecer nela uma validade passível de ser aplicada ao caso concreto como fundamento jurídico de uma decisão judicial ${ }^{69}$. Neste aspecto, a Lex Mercatoria, quando admitida pelo ordenamento estatal, figura numa relação de subordinação, na medida em que carece do reconhecimento do Estado.

Um segundo critério de classificação da relação entre ordenamentos diz respeito à extensão recíproca dos respectivos âmbitos de validade. Assim, há três tipos de relação: a) de exclusão total (os âmbitos de validades dos ordenamentos são delimitados de forma que não se sobrepõem, típico dos ordenamentos estatais, que se excluem totalmente, via de regra); b) de inclusão total (ocorre quando um dos dois ordenamentos tem um âmbito de validade que

65 COSTA, Cynara, de Barros. A verdadeira Lex Mercatoria: o direito além do Estado: um estudo sobre as antigas e novas teorias da Lex Mercatoria. Dissertação (Mestrado em Direito) - Universidade Federal de Pernambuco, Recife, 2011. Disponível em: https://repositorio.ufpe.br/bitstream/123456789/4772/1/arquivo6701_1.pdf. Acesso em: 22 set. 2021.

66 "A sociedade contemporânea tem a marca da complexidade". A expressão é de BARROSO, Luís Roberto. A razão sem voto: o STF e o governo da maioria. In: CONGRESSO BRASILEIRO DE DIREITO DO ESTADO, 15., 2015.

67 BOBBIO, Norberto. Teoria do Ordenamento Jurídico. Trad. Ari Marcelo Solon. 2. ed. São Paulo: Edipro, 2020. p. 152.

68 Idem, p. 155

69 ARLOTA, Alexandre Sales Cabral. O enquadramento dos contratos internacionais em face da lex mercatoria e a busca de estabilidade nas relações transfronteiriças. Revista da Faculdade de Direito da UERJ, Rio de Janeiro, v. 6. n. 26,2014 


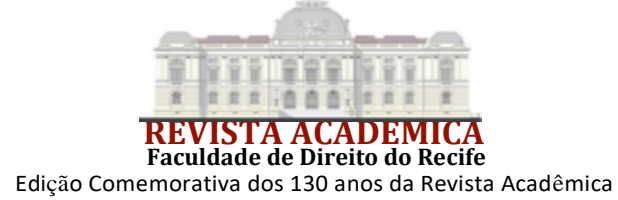

compreende totalmente o outro, como ocorre, por exemplo, na relação entre o ordenamento de um Estado-membro e a sua federação); e c) de exclusão parcial ou inclusão parcial (presente quando dois ordenamentos tem parte partes em comum, quando o Estado assimila parte de um ordenamento diferente. A Commonwealth pode ser um exemplo válido) ${ }^{70}$.

A relação da Lex Mercatoria com os ordenamentos estatais não representa um exemplo de exclusão total, uma vez que sua utilização pode ser admitida pelo ordenamento interno, limitada sempre pela ordem pública ${ }^{71}$. Também não representa um exemplo de inclusão total, pois, como visto, os ordenamentos estatais possuem restrições em considera-la como norma jurídica válida, além de não possuir uma delimitação facilmente constatável que permitisse sua inclusão total. A classificação mais próxima no âmbito da validade é, certamente, a de inclusão parcial, sendo a Lex Mercatoria admitida no caso concreto, desde que escolhida pelas partes e que não contrarie da ordem pública.

O terceiro tipo de relações entre ordenamentos toma por base a validade que um determinado ordenamento atribui às regras dos outros ordenamentos com os quais se relaciona, que podem ser de três ordens: a) indiferença (quando um ordenamento considera lícito o que em outro é obrigatório); b) recusa (quando um ordenamento considera proibido o que em outro é obrigatório, e vice-versa); e c) absorção (quando um ordenamento considera obrigatório ou proibido o que em outro igualmente é obrigatório ou proibido). Para Bobbio, esta última acepção pode assumir ainda duas formas: 1) reenvio (o procedimento pelo qual um ordenamento deixa de regular determinada matéria e acolhe a regulamentação feita por outro ordenamento); e 2) recepção (o procedimento no qual o ordenamento incorpora ao próprio sistema a disciplina estabelecida por outro ordenamento).

De modo interessante, quanto a este terceiro tipo de relações entre ordenamentos, a Lex Mercatoria pode apresentar cada uma das três ordens, em momentos distintos. Assim, pode ser indiferente a um ordenamento estatal que considere lícitas suas disposições; pode também ser recusada por um ordenamento estatal se este considerar as disposições da Lex Mercatoria incompatíveis com a ordem pública interna, por exemplo; e pode ser absorvida por um ordenamento estatal, tanto através de reenvio, se legalmente permitido; como através de recepção, quando o legislador interno codifica normas da Lex Mercatoria, ou quando o Judiciário utiliza elementos desta em suas decisões.

O certo é que, no que tange ao elemento de relações entre os ordenamentos jurídicos, a primeira classificação (feita com base no grau de validade das normas que um ordenamento confere ao outro) aparenta ser a mais relevante e substancial neste ponto do debate, na medida em que, na hipótese de um ordenamento estatal estabelecer com outro ordenamento uma relação de subordinação, os outros dois critérios de classificação (extensão recíproca dos respectivos âmbitos de validade e validade que um determinado ordenamento atribui às regras dos outros ordenamentos com os quais se relaciona) restariam prejudicados.

E como analisado acima, a relação entre um ordenamento estatal e a Lex Mercatoria, no que tange ao grau de validade que eles têm um em relação ao outro, cuida tipicamente de uma relação de subordinação, posto que, via de regra os ordenamentos estatais não reconhecem na Lex Mercatoria uma paridade jurídica.

\section{CONSIDERAÇÕES FINAIS}

70 BOBBIO, Norberto. Teoria do Ordenamento Jurídico. Trad. Ari Marcelo Solon. 2. ed. São Paulo: Edipro, 2020. p. 156.

${ }^{71}$ Daniel Sarmento subdivide esta em duas: "autonomia pública do cidadão e da autonomia privada do indivíduo". In: SERMENTO, Daniel. O Neoconstitucionalismo no Brasil: riscos e possibilidades. Revista Brasileira de Estudos Constitucionais, v. 9, p. 24; 95-133, 2009. 


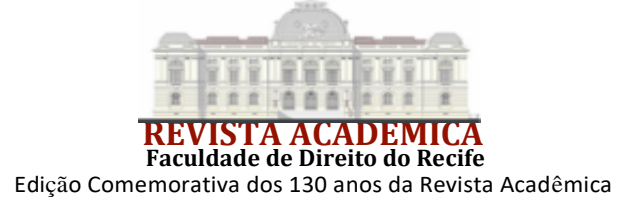

Dadas essas balizas, a conclusão a que chega o presente trabalho é que a Lex Mercatoria não apresenta as características apontadas por Bobbio como individualizadoras de um ordenamento jurídico, e, portanto, esse conjunto de normas que regem o comércio internacional não constitui Direito, ante a ausência dos elementos diferenciadores já tratados.

Não se trata de afirmar que sob nenhuma ótica a Lex Mercatoria poderia ser considerada uma ordem jurídica, o que caracterizaria inclusive uma presunção que o presente trabalho não pretende nem deseja abraçar, além de incompatível com o próprio senso de dúvida constante, essência do racionalismo e empirismo marcantes do pensamento acadêmico.

Como demonstrado, a intenção proposta foi especificamente analisar se, sob a ótica da Teoria do Ordenamento Jurídico, a Lex Mercatoria poderia ser considerada Direito, compreendido aqui enquanto ordenamento jurídico; ao passo que o que se evidenciou foi um resposta negativa ao referido questionamento, uma vez que o corpo de normas do comércio internacional não apresenta, na visão de Bobbio, os elementos especialíssimos que caracterizam o Direito, dotados de uma peculiaridade e normatividade específica ${ }^{72}$.

Também não é intenção deste artigo, ainda, fazer uma mera defesa do positivismo jurídico, linha de pensamento que rechaça a existência de outro direito que não o emanado pelo Estado, até porque, em primeiro plano, essa teoria certamente possui críticas relevantes, e, em segundo plano, fugiria ao recorte temático.

Nesse esteio, o presente trabalho não visa se impor como um dado crucial que põe à prova uma teoria ${ }^{73}$ ou a pesquisa já realizada por tantos estudiosos do tema, nem olvida que outros autores com vasto conhecimento sobre a Lex Mercatoria (como Cynara de Barros Costa, que desenvolveu justamente uma teoria afirmativa da natureza jurídica da Lex Mercatoria) tenham chegado à conclusões diversas da exposta no presente trabalho, e reconheçam nestas regras do comércio internacional o caráter jurídico não encontrado pelo presente artigo. Possivelmente, a explicação para as divergências de conclusões quanto à natureza jurídica da Lex Mercatoria seja fruto dos distintos recortes teóricos adotados.

Contudo, a mera constatação de que a Lex Mercatoria não constitui ordem jurídica não a torna irrelevante ou, muito menos, ineficaz na dinâmica do comércio internacional. O fato é que suas normas e as sanções por elas previstas são amplamente utilizadas na regulação das transações comerciais transnacionais, e sua importância tende a crescer ainda mais no futuro, com a cada vez mais relevante atuação das cortes arbitrais especializadas ${ }^{74}$.

Desse modo, uma das repercussões concretas trazida pelo caráter não-jurídico da Lex Mercatoria é que suas normas podem ser compreendidas enquanto expressões de Economia, por exemplo, e igualmente suas sanções são econômicas, mas não jurídicas. Em que pese o Direito não possa ser desvinculado da economia, posto que "é uma expressão correta e, portanto, não ideológica, da realidade econômica ${ }^{75}$ ", ante a diferenciação do esquema cognitivo relativo às duas ciências $^{76}$, não é possível, à luz da Teoria do Ordenamento Jurídico, classificar como jurídico aquilo que não apresenta os elementos diferenciadores do Direito.

Obviamente, o comércio internacional não é um campo que se traduz em um estado de natureza, ou um domínio da anarquia, ou é regido por um direito natural que considera as transações internacionais como um direito básico $\operatorname{seu}^{77}$, parafraseado João Ubaldo Ribeiro.

72 MÜLLER, Friedrich. Teoria jurídica estruturante. p. 13

73 POSSENTI, Sirio. O dado dado e o dado dado. Os limites do discurso. Curitiba: Criar, 2002. p. 27-37.

74 COSTA, Cynara de Barros. Direito Transnacional do Comércio... p. 241-242.

75 KELSEN, Hans. A Teoria Comunista do Direito. Trad. Pedro Davoglio. São Paulo: Contracorrente, 2021. p. 23.

${ }^{76}$ MARCUSCHI, Luiz Antônio. Processos de compreensão. Produção textual, análise de gênero e compreensão. São Paulo: Parábola 2008. p. 228.

77 Expressão de João Ubaldo Ribeiro: "Para hematófagos, beber sangue é algo natural e, se pudessem pensar, considerariam isso um direito básico deles". In: O Sorriso do Lagarto. Rio de Janeiro: Nova Fronteira, 1989. p. 96.

SILVA, Madson Douglas Xavier da; BÔAVIAGEM, Aurélio Agostinho da. A LEX MERCATORIA ENQUANTO DIREITO: UMA ANÁLISE DA NATUREZA DAS NORMAS QUE REGEM O COMÉRCIO INTERNACIONAL À LUZ DA TEORIA DO ORDENAMENTO JURÍDICO DE NORBERTO BOBBIO. Revista Acadêmica da Faculdade de Direito do Recife - ISSN: 24482307, Edição Comemorativa dos 130 anos da Revista Acadêmica, p. 178-198. Nov. 2021. ISSN 2448-2307. <Disponível em: https://periodicos.ufpe.br/revistas/ACADEMICA/article/view/252575> 


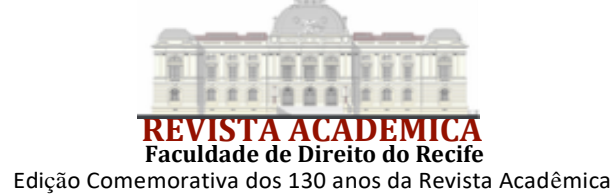

Obviamente há regramento. Contudo, este regramento não é jurídico, mas, em grande medida, econômico. Exigir que no âmbito do comércio internacional a Lex Mercatoria possuísse indispensavelmente um caráter jurídico para que fosse eficaz seria desconsiderar os efeitos práticos dos acordos econômicos que servem às transações comercias; bem como alçaria o Direito a um patamar de supranacionalidade universal, o que, evidente, é impossível neste momento da História.

Por fim, adentrar no debate se a Lex Mercatoria, enquanto mecanismo de regulação econômica do comércio internacional, possui eficácia satisfatória e tem suas normas observadas na práxis mercantil; ou se necessitaria de uma roupagem jurídica para melhor atender à finalidade da regência do comércio transnacional ou tornar vinculantes suas determinações; já cuidaria de questionamentos que extrapolariam as finalidades e o objeto do presente artigo, sendo que este ponto colateral seria melhor abordado em um eventual estudo futuro.

\section{REFERÊNCIAS}

ALEXY, Robert. Teoria dos Direitos Fundamentais. Trad. Virgílio Afonso da Silva. São Paulo: Malheiros, 2008.

ALEXY, Robert. Teoria da Argumentação Jurídica. Trad. Zilda Hutchinson Schild Silva. São Paulo: Landy, 2001.

ARLOTA, Alexandre Sales Cabral. O enquadramento dos contratos internacionais em face da lex mercatoria e a busca de estabilidade nas relações transfronteiriças. Revista da Faculdade de Direito da UERJ, Rio de Janeiro, v. 6. n. 26, 2014.

ARZA, Eugênia Cristina Nilsen Ribeiro; GUIMARÃES, Marcelo Cesar. A atuação empresarial transnacional: conceito, formas de atuação, efeitos e perspectivas para a regulamentação. Revista Acadêmica da Faculdade de Direito do Recife, Recife, v. 87, n. 2, p. 49-71, 2015.

ARZA, Eugênia Cristina Nilsen Ribeiro; GUIMARÃES, Marcelo Cesar. Os Princípios da Haia sobre a Escolha da Lei Aplicável aos Contratos Comerciais Internacionais. Fortaleza: UNIFOR. In: CONGRESSO BRASILEIRO DE DIREITO INTERNACIONAL. CODIFICAÇÃO DO DIREITO INTERNACIONAL, 2015. v. 1, p. 1-12.

BAPTISTA, Luiz Olavo. Contratos Internacionais. São Paulo: Lex Magister, 2011.

BARROSO, Luís Roberto. A razão sem voto: o STF e o governo da maioria. In: CONGRESSO BRASILEIRO DE DIREITO DO ESTADO, 15., 2015.

BÔAVIAGEM, Aurélio Agostinho da. A ordem pública: limite da autonomia da vontade na escolha da lei aplicável. Anuário dos Cursos de Pós-Graduação em Direito (UFPE), Recife, v. 16. p. 25-36, 2006.

BÔAVIAGEM, Aurélio Agostinho da. O Estado como parte contratante nas relações comerciais internacionais - uma releitura do exercício da soberania à luz da "nova nova" Lex Mercatoria. Revista de Direito Internacional Econômico e Tributário, Brasília, v. 13, n. 2, p. 364-382, 2018.

BÔAVIAGEM, Aurélio Agostinho da. Sobre princípios dos contratos internacionais de comércio. Revista Acadêmica da Faculdade de Direito do Recife, Recife, v. 88, n. 2, p. 63-81, 2016. 
BOBBIO, Norberto. Teoria da Norma Jurídica. Trad. Fernando Pavan Baptista e Ariani Bueno Sudatti. 6. ed. Bauru: Edipro, 2019.

BOBBIO, Norberto. Teoria do Ordenamento Jurídico. Trad. Ari Marcelo Solon. 2. ed. São Paulo: Edipro, 2020.

BONAVIDES, Paulo. Curso de Direito Constitucional. 15. ed. São Paulo: Malheiros, 2004.

COSTA, Cynara, de Barros. A verdadeira Lex Mercatoria: o direito além do Estado: um estudo sobre as antigas e novas teorias da Lex Mercatoria. Dissertação (Mestrado em Direito) Universidade Federal de Pernambuco, Recife, 2011.

COSTA, Cynara, de Barros. Direito Transnacional do Comércio: Uma teoria afirmativa da natureza jurídica das normas do comércio transnacional, 2016. Tese (Doutorado em Direito) Universidade Federal de Pernambuco, Recife, 2016.

ECO, Humberto. Interpretação e superinterpretação. São Paulo: Martins Fontes, 1997. p. 55-56. GAMA JR., Lauro. Contratos Internacionais à luz dos Princípios do UNIDROIT 2004: soft law, arbitragem e jurisdição. Rio de Janeiro: Renovar, 2006.

HATZIMIHAIL, Nikitas E. The Many Lives and faces of Lex Mercatoria: History as genealogy in international business law. Law and contemporary problems, v. 71, n. 169, 2008.

IP, Eric C. Globalization and the future of the law of the sovereign state. I Con, v. 8, n. 3, p. 636655,2010

KELSEN, Hans. A Teoria Comunista do Direito. Trad. Pedro Davoglio. São Paulo: Contracorrente, 2021.

KELSEN, Hans. Teoria Pura do Direito. Trad. João Baptista Machado. 8. ed. São Paulo: WMF Martins Fontes, 2009.

KRELL, Andreas. A recepção das teorias alemãs sobre "conceitos jurídicos indeterminados" e o controle da discricionariedade no Brasil. Interesse Público, Porto Alegre, v. 23, p. 21-49, 2004.

KRELL, Andreas. Entre desdém teórico e aprovação na prática: os métodos clássicos de interpretação jurídica. Revista Direito GV, São Paulo, v. 10, n. 1, p. 295-320, jan./jun. 2014.

LORETO, Sylvio; BARBOSA, Pedro Henrique de Faria. O mito de Jano: as duas faces da ordem pública no Direito Internacional Privado. Revista Interação, Santa Maria, v. 12, n. 12, p. 103$118,2017$.

MARCUSCHI, Luiz Antônio. Processos de compreensão. Produção textual, análise de gênero e compreensão. São Paulo: Parábola 2008.

MEURER, Cesar. A Teoria correspondentista da Verdade. Apresentação e crítica lógicosemântica. Porto Alegre: FI, 2018.

MICHAELS, Ralf. Globalization and Law: Law Beyond the State. Durhan: Law and Society Theory (Banakar and Travers eds., forthcoming), 2013. 
MÜLLER, Friedrich. O novo paradigma do direito: introdução à teoria e metódica estruturantes. 3. ed. São Paulo: Revista dos Tribunais, 2013.

MÜLLER, Friedrich. Teoria jurídica estruturante. São Paulo: Revista dos Tribunais, 2008.

NESTOR, Odilon. Direito Internacional Privado. Execução das sentenças estrangeiras e os effeitos dessas sentenças fora do Estado onde foram proferidas. Revista Acadêmica da Faculdade de Direito do Recife, Recife, v. 22, n. 1, 1914.

POSSENTI, Sirio. O dado dado e o dado dado. Os limites do discurso. Curitiba: Criar, 2002. p. 27-37.

SARMENTO, Daniel. O Neoconstitucionalismo no Brasil: riscos e possibilidades. Revista Brasileira de Estudos Constitucionais, v. 9, p. 95-133, 2009.

SILVA, Virgílio Afonso da. Interpretação constitucional e sincretismo metodológico. In: INTERPRETAÇÃO constitucional, São Paulo: Malheiros, 2005. p. 115-143.

TARTUCE, Flávio. Manual de Direito Civil. 10. ed. Rio de Janeiro: Forense: São Paulo: Método, 2020. Volume único.

VIANNA, Sâmila Nunes. O sistema de precedentes na arbitragem internacional: perspectivas na jurisprudência arbitral comercial. Dissertação (Mestrado em Direito) - Universidade Federal de Pernambuco, Recife, 2021. 